National Comorbidity Survey Replication. Arch Gen Psychiatry 2005; 62 : 593-602.

6 Wittchen $\mathrm{H}-\mathrm{U}$, Jacobi F. Size and burden of mental disorders in Europe - a critical review and appraisal of 27 studies. Eur Neuropsychopharmacol 2005; 15: $357-76$

7 Williams DR, Herman A, Kessler RC, Sonnega J, Seedat S, Stein DJ, Moomal H, Wilson CM. The South African Stress and Health Study: rationale and design. Metab Brain Dis 2004; 19: 135-47.

8 Kish, L. A procedure for objective respondent selection within the household. J Am Stat Assoc 1949; 44: 380-7.

9 Kessler RC, Ustun TB. The World Mental Health (WMH) Survey Initiative Version of the World Health Organization (WHO) Composite International Diagnostic Interview (CIDI). Int J Methods Psychiatr Res 2004; 13: 93-121.

10 American Psychiatric Association. Diagnostic and Statistical Manual of Mental Disorders (4th edn) (DSM-IV). 1994; APA.

11 Allison, PD. Discrete-time methods for the analysis of event histories. Social Methodol 1982; 13: 61-98.

12 Gureje O, Lasebikan VO, Kola L, Makanjuola VA. Lifetime and 12-month prevalence of mental disorders in the Nigerian Survey of Mental Health and Well-Being. Br J Psychiatry 2006; 188: 465-71.

13 Lalloo R, Myburgh NG, Smith MJ, Solanki GC. Access to health care in South Africa - the influence of race and class. S Afr Med J 2004; 94: 639-42.

14 WHO International Consortium in Psychiatric Epidemiology. Cross-national comparisons of the prevalences and correlates of mental disorders. Bull World Health Organ 2000; 78: 413-26.

15 Kessler RC, Wittchen H-U, Abelson JM, McGonagle KA, Schwarz, N, Kendler KS, Knauper B, Zhao S. Methodological studies of the Composite
International Diagnostic Interview (CIDI) in the US national comorbidity survey (NCS). Int J Methods Psychiatr Res 1998; 7: 33-5.

16 Haro J-M, Arbabzadeh-Bouchez S, Brugha TS, de Girolamo G, Guyer ME, Jin R., Lepine J-P, Mazzi F, Reneses B, Vilagut G, Sampson NA, Kessler RC. Concordance of the Composite International Diagnostic Interview Version 3.0 (CIDI 3.0) with standardized clinical assessments in the WHO World Mental Health Surveys. Int J Methods Psychiatr Res 2006; 15: 167-80.

17 Horwath E, Lish JD, Johnson J, Hornig CD, Weissman MM. Agoraphobia without panic: clinical reappraisal of an epidemiologic finding. Am J Psychiatry 1993; 150: 1496-501.

18 Wittchen $\mathrm{H}-\mathrm{U}$, Zhao S, Abelson JM, Abelson JL, Kessler RC. Reliability and procedural validity of UM-CIDI DSM-III-R phobic disorders. Psychol Med 1996; 26: 1169-77.

19 Rumble S, Swartz L, Parry C, Zwarenstein M. Prevalence of psychiatric morbidity in the adult population of a rural South African village. Psychol Med 1996; 26: 997-1007.

20 Carey PD, Stein DJ, Zungu-Dirwayi N, Seedat S. Trauma and posttraumatic stress disorder in an urban Xhosa primary care population: prevalence, comorbidity and service use patterns. J Nerv Ment Dis 2003; 191: 230-6.

21 Kirmayer L. The place of culture in psychiatric nosology: taijin kyofusho and DSM-III-R. J Nerv Ment Dis 1991; 179: 19-28.

22 Chisholm D, Sanderson K, Ayuso-Mateos JL, Saxena S. Reducing the global burden of depression: population-level analysis of intervention costeffectiveness in 14 world regions. Br J Psychiatry 2004; 184: 393-403.

23 Stein DJ, Gureje O. Depression and anxiety in the developing world: is it time to medicalise the suffering? Lancet 2004; 364: 233-4.

24 Seedat S, Emsley RA, Stein DJ. Land of promise: challenges and opportunities for research in South Africa. Mol Psychiatry 2004; 9: 891-2.

\title{
Dementia with Lewy bodies
}

\section{Ian McKeith}

Every seven seconds there is a new case of dementia worldwide. Pathological studies suggest that $10-15 \%$ of cases are dementia with Lewy bodies (DLB), a diagnosis unrecognised 15 years ago. The functional impairments and costs of managing this illness are twice those of Alzheimer's disease and one in four carers rates quality of life in DLB as 'worse than death'. Correct management brings significant benefits, but DLB is only part of a spectrum of Lewy body disorders including Parkinson's disease and autonomic failure, which present to psychiatrists, neurologists, geriatricians and general practitioners. To beat it we must talk more with colleagues and cut across specialty boundaries. 